\title{
FORMULA METHOD FOR ECONOMIC VALUATION OF URBAN FOREST
}

\author{
Bruna Lara Arantes ${ }^{1}$, Rafaela Novaes Abreu ${ }^{1}$, Demóstenes Ferreira da Silva Filho ${ }^{1}$ \\ 1Universidade de São Paulo - ESALQ. E-mail: blarantes@usp.br; rafabreu@usp.br; dfilho@usp.br
}

\section{ABSTRACT}

Trees in urban settings provide several benefits and the value of these benefits is calculable. Urban forest economic valuation has been increasingly applied to facilitate and justify expenditures, more efficiently manage trees, serve as a tool to define costs and benefits, adjust project priorities and policies, and assign a value to environmental impacts. This study was designed to evaluate urban forest samples in two of the city of São Paulo's administrative districts, Itaim Paulista and Nossa Senhora do Ó, and propose improvements to the existing formula method used to evaluate these assets. The two districts' tree components are currently valued at US\$ 85,165.51 and US\$ 66,814.838, have a $\mathrm{m}^{2}$ valuation of US\$ 2.71 and US\$2.12 respectively. Applying the developed formula showed that the formula improvements did differences in these values in $51 \%$. It is recommended that this new formula method should be considered as a new model for urban forest valuation research.

Keywords: Street trees, forest inventory, monetary

\section{VALORAÇÃO ECONÔMICA DA FLORESTA URBANA POR MÉTODO FÓRMULA}

\section{RESUMO}

Árvores nas cidades possibilitam diversos benefícios, e com isso, a valoração econômica da arborização urbana tem sido cada vez mais explorada no planejamento e gestão, servindo para definição de custos, prioridades em projetos, políticas públicas e no cálculo de pagamentos por serviços ambientais. A valoração das árvores pode conferir valor às propriedades de imóveis, além de auxiliar no gerenciamento da floresta urbana. Esse estudo valorou uma amostra da floresta urbana dos Distritos Administrativos de Itaim Paulista e Nossa Senhora do Ó, da cidade de São Paulo, e propôs aprimoramentos ao método fórmula existente na literatura. No total, os componentes arbóreos dos

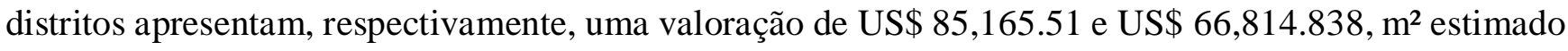
em US\$ 2.71 e US\$ 2.12, sendo que os aperfeiçoamentos no método fórmula mostraram-se positivos, 
com diferenças de até $51 \%$ entre os valores obtidos, devendo ser considerados como o novo modelo para pesquisas em valoração.

Palavras-chave: Árvores de calçadas, inventário florestal, monetário

\section{INTRODUCTION}

The presence of trees in an urban setting provides several environmental and economic benefits for the residents. The benefits are numerous, such as energy saving in buildings adjacent to wooded areas, atmospheric carbon absorption stimulate, water runoff controls while improving psychological wellbeing (RHODES et al., 2011; SEAMANS, 2013).

Determining the value of all the services provided by urban forest has come to be of increasing importance to urban planning departments, especially when allocating resources to manage these areas. Urban forests can be individual trees or larger areas covered with trees or shrubs. These green spaces are valued to determine the environmental services and public welfare they provide, not to put them on sale (FALCO, 2010). Additionally, without an economic valuation, no cost benefit calculation is possible, tree removal and planting projects become subjective exercises, the design and prioritization of policies where trees are involved has no basis, and the calculation of rational remuneration for negative environmental impacts of tree plantings or removals is impossible (LO \& JIM, 2010). Proper urban forest management depends on understanding the value of the good that is being managed.

This valuation can be carried out from several perspectives, among them the forest's value as a capital asset, as factors needed to maintain biological and ecological sustainability; and as instruments that aid in environmental management (MOTA, 2001). While planted forests produce material goods for the market, urban trees often increase property values (EDWARDS, 1992) and produce goods in the form of value adding public benefits (WOLF, 2004).

Different modalities of use and non-use can be linked with urban forest value. Use value is the value attributed to forests use in the present or future. There are three categories of urban forest use value: direct value, such as seeds used to produce seedlings or handicrafts; indirect value, which are the environmental, aesthetic and social benefits provided by urban vegetation; and the option value, corresponding to tree seedlings planted for future benefits. Non-use value has only one category, the existence value: people know that the trees are there. This is similar to estimating the value of a national park: just the knowledge that the park is there has value. For Gray \& Deneke (1986), urban forests affect 
property values, maintenance expenditures; legal costs; the value of city infrastructure. All the above mentioned costs and benefits can be determined using the proper formula method.

In the 1960s, urban forest modeling began to quantify and evaluate the environmental services them provide. Efforts initiated by the Chicago Urban Forest Climate Project led to the design of the first American model valuing urban forest's environmental benefits (SILVA FILHO \& TOSETTI, 2010).

Urban forest valuation is usually conducted using a contingent, hedonic valuation formula method (VIANA et al., 2012). The contingent valuation is conducted through interviews to find out how much individuals are willing to pay for environmental benefits derived from urban forests (LO \& JIM, 2010). Hedonic valuation would be to put a value on the influence the environmental service provided by the urban forest has on a material good's price, such as to increase in the value of a property located near a wooded area (SANDER et al., 2010). These properties would, most likely, have better air quality and be more valuable that those without this benefit, which should be an incentive to expand urban forest for both the property owner and the city's residents in general (SMITH \& HUANG, 1995).

The "formula" is one of the most used methods for valuing trees. Among the most used formulas recognized by the scientific community are the "Guide for Plant Appraisal"; Norma Granada; "Burnley"; "Helliwell"; and "STEM [Standard Tree Evaluation Method]" (WATSON, 2002; AYUGA-TÉLLEZ et al., 2011).

Determining values of urban trees in an urban setting sets parameters for the application of resources to manage and conserve them. A combination of parameters was used to value urban trees, such as general condition, location, biometric value, condition value, and species value. The tree's value can be used to convey to urban citizens the importance of trees as part of the city's infrastructure and helps them understand connection between forest and the urban environment (SILVA FILHO \& TOSETTI, 2010).

This study modified an existent formula method to improve urban forest valuation techniques. This paper presents a discussion of the adapted formula and demonstrates the proposed formula method's applicability.

\section{MATERIALS AND METHODS}

This research is based on the formula developed by Potenza (2016). In this research, Potenza's (2016) formula is modified, and the modified version is used to design a model that estimates the value urban forest in two Administrative Districts (AD) in the city of Sao Paulo, Brazil. 


\section{Method improvement}

Formula methods are employed to assign monetary value to urban forest through application of basic inventory data (WATSON, 2002). The use of a defined formula sets criteria for the identification of an urban forest characteristics and facilitates assignment of a positive or negative value to these characteristics' interactions with the urban environment, expressing these interactions through mathematical operations.

The Potenza (2016) formula, which is an improvement of the Silva Filho et al. (2002) original formula, and will be used in this research, proposes an increase in the importance given to large sized not frequent native trees, in depreciation of those of smaller size, high frequency and low phytosanitary condition, adding an Ecological Adequacy (EA) index in the Species Value (SV) calculation, which proved to be significantly important for monetary results. The Potenza (2016) formula can be expressed by equation (1):

$$
\text { Tree value }=\left(\frac{\mathrm{II}+\mathrm{RII}}{2}\right) * \mathrm{Kr}
$$

Where, II = Importance Index; IIR = Relative Importance Index; Kr = constant.

The Species Value index, which is given by equation 2, has its value included in the Importance Index (II) calculation.

$\mathrm{SV}=\frac{\mathrm{A}+\mathrm{DP}+\mathrm{AD}+\mathrm{D}+\mathrm{EA}}{5}$

Where, $\mathrm{A}=$ availability; $\mathrm{DP}=$ desirable parts; $\mathrm{AD}=$ adaptability; $\mathrm{D}=$ development; $\mathrm{EA}=$ ecological adequacy.

This index predicts key items in urban forest analysis, and can be found in several surveys, such as:

- Invasive species use penalization: it is known that biological invasion is one of the main responsible for the biodiversity loss in the world due to the adaptive ability of some species (PRIMACK \& RODRIGUES, 2006), and in urban forests such concept should be considered. A study, in the city of Maringá, state of Paraná, Brazil, pointed out that only $24.1 \%$ of the species are native to the biome that 
the city is inserted, with $18.4 \%$ being invasive, represented by species such as Hovenia dulcis and Leucena leucocephala (BLUM et al., 2008).

- Penalization of the use of species with characteristics that are not suitable for its localization, such as: Ficus benjamina, which has invasive roots that can damage even walls and pipelines (ROCHA et al., 2004), are recommended in squares and free areas with availability for their free development, or species such as the genus Acer for producing allergic pollen (ITO et al., 2015; LOVASI et al., 2013).

- Native species at risk of extinction use valuation: native species at risk of extinction should be the target of conservation strategies, including urban forests, such as the case of Caesalphina echinata, an Atlantic Forest species declared at risk of extinction (IBAMA Decree n.37-N, April 3, 1992), since cities can be used for the ex situ species conservation, such as the city of Rio de Janeiro and Recife (ROCHA \& BARBEDO, 2008).

- Development: the species growth rate is a fundamental element of its management, considering the space availability in the environment for it to develop and which ecosystem services will be most urgent for that region. For example, if the objective is shade, one should opt for a taller, wider canopy, which usually has a slower development, which can be combined with faster growing trees that generate a shading, and then can be suppressed by the shadow of the larger ones (MASCARÓ \& MASCARÓ, 2010).

This study proposes an improvement for the Potenza's (2016) formula. The proposed changes include an analysis that values the tree species to the detriment of the shrub species, ensuring that these smaller plants do not obtain the same valuation index as the larger plants.

For a species to be considered arboreal, it must have a woody morphological structure with main trunk from which high branches appear, and height between 4 to 6 meters for a small tree, and above 10 meters for a big tree, according to Mascaró \& Mascaró (2010). On the other hand, the same study defined shrubs as plants that will be 6 meters of height, no more, with a stem that branches from the base, a woody or semi-woody structure, no main trunk but several similar trunks, and commonly associated with landscaping.

In urban settings, taller trees provide more benefits than shrubs: Their canopy and branches can be above electric power lines ( 8 to 10 meters), which will significantly reduce the risk of conflict with the power grid and the need for drastic pruning; a greater branching height for sidewalk plantings allows pedestrians to pass freely below them and provides aesthetics improvements; and finally, trees with higher DBH (Diameter at Breast Height) are considered older and have considerable biomass that 274 
provides greater carbon absorption to helps reduce the greenhouse effect (FAUSET et al., 2015). In addition, large trees mean greater shade, hence greater energy savings and less extreme temperature variations, greater air cleanliness and a positive respiratory impact; and better rain/hail impact management.

The average benefits from a large tree in an urban forest are US\$80 - US\$120/year, the average benefits of a shrub or small tree are US\$15/year (CENTER FOR URBAN FOREST RESEARCH, 2006). This data should reduce the use of frequently planted urban shrubs, such as Murraya paniculata, Terminalia catappa, and Caesalpinia phulcherrima, to the benefit of trees species.

\section{$\underline{\text { Data }}$}

To analyze the proposed adjustments feasibility, two Administrative Districts of Sao Paulo city were selected based on data provided by the Urban Forestry Laboratory/ESALQ-USP, from a complete urban forestry inventory made on January 2016 (ARANTES, 2017).

The Sao Paulo city is in the state of Sao Paulo, Brazil and is one of the largest metropolises in the world. From 2000 to 2010, the Sao Paulo population grew by an average of $0.76 \%$ per year, and the urbanization rate increased from $94.05 \%$ to $99.01 \%$, with $11,253,503$ million inhabitants (ATLAS BRASIL, 2010).

The research study area is the Itaim Paulista AD, located at São Paulo's most eastern extreme, and the Nossa Senhora do Ó AD, located in the city's northwest (Figure 1). Trees within 100m radius from a geo-referenced location at these sites were inventoried creating a random sample of the AD tree population (Figure 2).

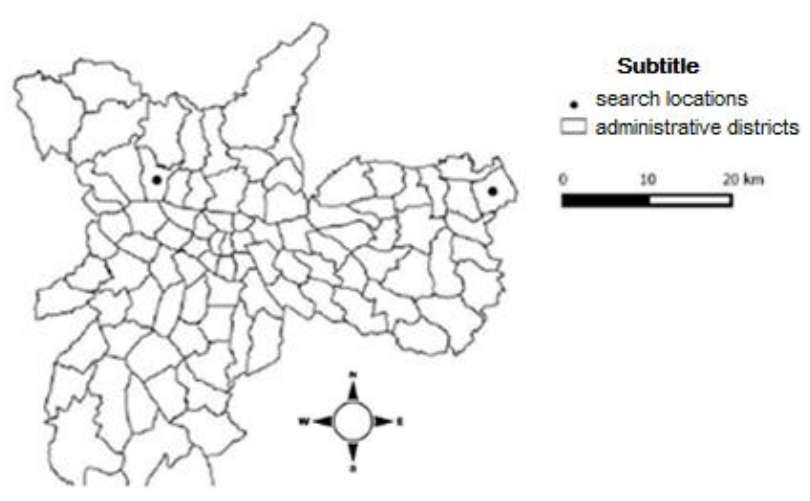

Figure 1. The Sao Paulo city Administrative Districts, Nossa Senhora do Ó is in the West (W) and Itaim Paulista in the extreme East (E). Source: Original research data 

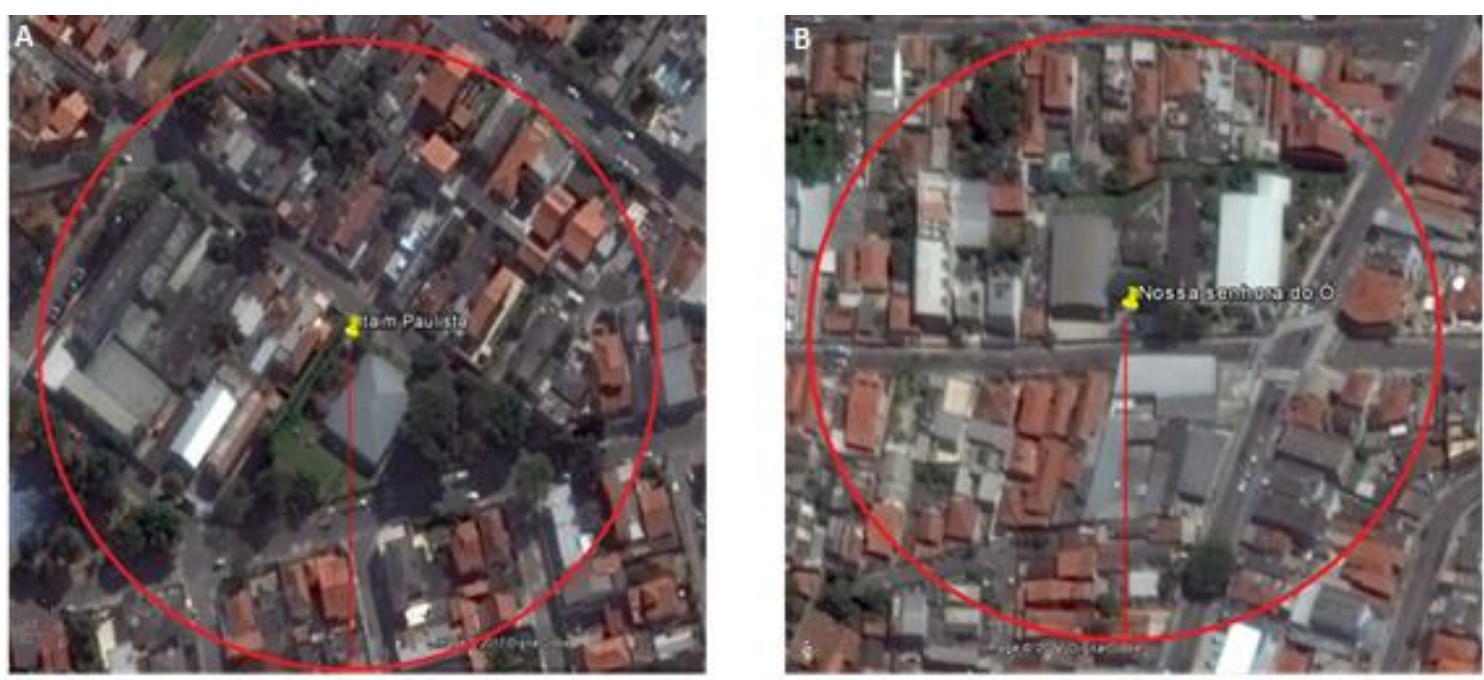

Figure 2. Study area delimited with a $100 \mathrm{~m}$ radius from the study area point. In A there is Itaim Paulista Administrative District and in B Nossa Senhora do Ó, both in Sao Paulo city. Source: Original data, made from Google Earth (2016)

\section{RESULTS AND DISCUSSION}

\section{Formula method improvement}

The SV index calculation was adjusted to increase the valuation of tree greater than for shrub species, with tree species SV index increased by 4 times over the shrub species standard valuation. The tree species SV index calculation is shown by equation (3) and the shrub species SV index calculation is shown by equation (4):

$\mathrm{TSV}=\frac{\mathrm{A}+\mathrm{DP}+\mathrm{AD}+\mathrm{D}+\mathrm{EA}}{5}$

Where, TSV $=$ tree species value

$\mathrm{SSV}=\frac{\mathrm{A}+\mathrm{DP}+\mathrm{AD}+\mathrm{D}+\mathrm{EA}}{20}$

Where, SSV = shrub species value

$\mathrm{Kr}$ constant formula was adjusted and now should be considered just the Relative Importance Index (RII) of tree species, and disregarding the RII of shrubs species with the lowest value, as it is demonstrated in equation (6):

$\mathrm{Kr}=\frac{\text { total planting cost (US\$) }}{\text { lowest RII value }}$ 


\section{$\underline{\text { Itaim Paulista AD }}$}

Within the selected sample area of $31,416 \mathrm{~m}^{2}$, there are 57 individual trees with an estimated monetary value of US\$ $85,165.51^{1}$, a per $\mathrm{m}^{2}$ value of US\$ 2.71 .

For $\mathrm{Kr}$ calculation was considered the total planting costs of US\$ 73.06 for Sao Paulo city (POTENZA, 2016) with the RII lowest value of 0.344 (Mangifera indica), generating a final $\mathrm{Kr}=212.38$.

The generate indexes for valuation calculation and the monetary values for each arboreal individual, for Itaim Paulista $\mathrm{AD}$, are listed in Table 1 and Table 2, respectively.

The evaluated trees with greater value were a Caesalpinia pluviosa (US\$ 4,674.95) being the tallest $(15,7 \mathrm{~m})$, a Ceiba speciosa (US\$ 4,607.24) had highest DBH $(1,16 \mathrm{~m})$, and a Ficus benjamina (US\$ $4,330.40)$ had the highest first offshoot value $(6,68 \mathrm{~m})$, being all them very interesting characteristics for urban forest and are valued by the formula method.

Table 1. Itaim Paulista Administration District indexes, being: condition value (CV), localization value (LV), biometric value (BV), specie value (SV), shrub specie value (SSV) specie frequency (\%), importance index (II) relativ e importance index (RII).

\begin{tabular}{lccccc}
\hline Scientific name & BV & $\begin{array}{c}\text { SV } \\
\text { SSV }\end{array}$ & \% & II & RII \\
\hline Persea americana & 1.34 & 1.4 & 3.51 & 7.51 & 2.14 \\
\hline Persea americana & 0.59 & 1.4 & 3.51 & 3.31 & 0.94 \\
\hline Ligustrum lucidum & 3.06 & 1.8 & 10.53 & 22.07 & 2.10 \\
\hline Ligustrum lucidum & 1.97 & 1.8 & 10.53 & 14.20 & 1.35 \\
\hline Ligustrum lucidum & 1.67 & 1.8 & 10.53 & 11.99 & 1.14 \\
\hline Ligustrum lucidum & 1.49 & 1.8 & 10.53 & 10.75 & 1.02 \\
\hline Ligustrum lucidum & 1.33 & 1.8 & 10.53 & 9.54 & 0.91 \\
\hline Ligustrum lucidum & 1.09 & 1.8 & 10.53 & 7.83 & 0.74 \\
\hline Morus nigra & 0.75 & 1.2 & 1.75 & 3.60 & 2.05 \\
\hline Roupala montana & 0.77 & 2.4 & 1.75 & 7.42 & 4.23 \\
\hline Schefflera actinophylla & 1.52 & 0.45 & 7.02 & 2.74 & 0.39 \\
\hline Schefflera actinophylla & 1.51 & 0.45 & 7.02 & 2.71 & 0.39 \\
\hline Schefflera actinophylla & 1.45 & 0.45 & 7.02 & 1.95 & 0.28 \\
\hline Schefflera actinophylla & 0.69 & 0.45 & 7.02 & 1.24 & 0.18 \\
\hline Cordia sp. & 2.14 & 2.2 & 7.02 & 18.80 & 2.68 \\
\hline Cordia sp. & 1.17 & 2.2 & 7.02 & 10.33 & 1.47 \\
\hline Cordia sp. & 1.12 & 2.2 & 7.02 & 9.84 & 1.40 \\
\hline
\end{tabular}

\footnotetext{
${ }^{1}$ All the values of the article were converted into US dollars, with quotation as of 01/19/2018 - R \$3,209 according to values of the Central Bank of Brazil (http://www4.bcb.gov.br/pec/taxas/batch/taxas.asp?id=txdolar)
} 
Table 1. Itaim Paulista Administration District indexes, being: condition value (CV), localization value (LV), biometric value (BV), specie value (SV), shrub specie value (SSV) specie frequency (\%), importance index (II) relativ e importance index (RII) (Continued).

\begin{tabular}{lccccc}
\hline Scientific name & BV & SV & \% & II & RII \\
\hline Cordia sp. & 1.08 & 2.2 & 7.02 & 9.48 & 1.35 \\
\hline Spathodea campanulata & 1.50 & 1.8 & 1.75 & 10.77 & 6.14 \\
\hline Ficus benjamina & 3.10 & 3 & 10.53 & 37.24 & 3.54 \\
\hline Ficus benjamina & 2.14 & 3 & 10.53 & 25.63 & 2.43 \\
\hline Ficus benjamina & 1.98 & 3 & 10.53 & 23.80 & 2.26 \\
\hline Ficus benjamina & 1.97 & 3 & 10.53 & 23.61 & 2.24 \\
\hline Ficus benjamina & 3.13 & 3 & 10.53 & 18.77 & 1.78 \\
\hline Ficus benjamina & 1.13 & 3 & 10.53 & 13.52 & 1.28 \\
\hline Ficus guaranitica & 1.46 & 3 & 1.75 & 17.54 & 10.00 \\
\hline Myrcia tomentosa & 0.93 & 1.4 & 3.51 & 5.22 & 1.49 \\
\hline Myrcia tomentosa & 0.66 & 1.4 & 3.51 & 3.69 & 1.05 \\
\hline Tabebuia sp. & 1.42 & 2.6 & 3.51 & 14.73 & 4.20 \\
\hline Tabebuia pentaphylla & 0.97 & 2.6 & 3.51 & 10.08 & 2.87 \\
\hline Myrciaria trunciflora & 0.99 & 3 & 1.75 & 11.93 & 6.80 \\
\hline Artocarpus heterophyllus & 1.29 & 2.2 & 1.75 & 11.37 & 6.48 \\
\hline Mangifera indica & 0.65 & 1.6 & 5.26 & 4.14 & 0.79 \\
\hline Mangifera indica & 0.46 & 1.6 & 5.26 & 2.98 & 0.57 \\
\hline Mangifera indica & 0.28 & 1.6 & 5.26 & 1.81 & 0.34 \\
\hline Licania tomentosa & 1.90 & 2.4 & 12.28 & 18.28 & 1.49 \\
\hline Licania tomentosa & 1.41 & 2.4 & 12.28 & 13.50 & 1.10 \\
\hline Licania tomentosa & 1.09 & 2.4 & 12.28 & 10.46 & 0.85 \\
\hline Licania tomentosa & 1.09 & 2.4 & 12.28 & 10.43 & 0.85 \\
\hline Licania tomentosa & 1.05 & 2.4 & 12.28 & 10.05 & 0.82 \\
\hline Licania tomentosa & 1.05 & 2.4 & 12.28 & 10.04 & 0.82 \\
\hline Licania tomentosa & 1.04 & 2.4 & 12.28 & 9.99 & 0.81 \\
\hline Ceiba speciosa & 3.52 & 2.4 & 3.51 & 33.76 & 9.62 \\
\hline Ceiba speciosa & 1.99 & 2.4 & 3.51 & 19.11 & 5.45 \\
\hline Roystonea sp. & 1.90 & 1.2 & 1.75 & 9.11 & 5.19 \\
\hline Bauhinia rufa & 0.95 & 1.8 & 5.26 & 6.82 & 1.30 \\
\hline Bauhinia rufa & 0.94 & 1.8 & 5.26 & 6.75 & 1.28 \\
\hline Bauhinia rufa & 0.76 & 1.8 & 5.26 & 5.45 & 1.04 \\
\hline Caesalpinia ferrea & 0.69 & 2.4 & 3.51 & 6.62 & 1.89 \\
\hline Caesalpinia ferrea & 0.56 & 2.4 & 3.51 & 5.41 & 1.54 \\
\hline Pinus sp. & 0.57 & 1.2 & 1.75 & 2.75 & 1.57 \\
\hline & & & & & $($ Continued) \\
\hline
\end{tabular}


Table 1. Itaim Paulista Administration District indexes, being: condition value (CV), localization value (LV), biometric value (BV), specie value (SV), shrub specie value (SSV) specie frequency (\%), importance index (II) relativ e importance index (RII) (Continued).

\begin{tabular}{lccccc}
\hline Eugenia uniflora & 0.69 & 3 & 1.75 & 8.29 & 4.73 \\
\hline Lagerstroemia indica & 1.43 & 3 & 1.75 & 4.28 & 2.44 \\
\hline Caesalpinia pluviosa & 3.19 & 2.2 & 1.75 & 28.04 & 15.98 \\
\hline Tipuana tipu & 1.84 & 2.2 & 3.51 & 16.15 & 4.60 \\
\hline Tipuana tipu & 0.81 & 2.2 & 3.51 & 7.13 & 2.03 \\
\hline Aleurites fordii & 1.53 & 2 & 1.75 & 12.24 & 6.97 \\
\hline Sil
\end{tabular}

Source: Original research data

Table 2. Individual and sample total results valuation of the Itaim Paulista administrative district urban forest, Sao Paulo, Brazil.

\begin{tabular}{lc}
\hline Scientific name & Monetary value (US\$) \\
\hline Persea americana & $1,024.66$ \\
\hline Persea americana & 451.74 \\
\hline Ligustrum lucidum & $2,566.17$ \\
\hline Ligustrum lucidum & $1,651.47$ \\
\hline Ligustrum lucidum & $1,394.42$ \\
\hline Ligustrum lucidum & $1,250.46$ \\
\hline Ligustrum lucidum & $1,109.38$ \\
\hline Ligustrum lucidum & 910.36 \\
\hline Morus nigra & 600.62 \\
\hline Roupala montana & $1,236.43$ \\
\hline Schefflera actinophylla & 332.64 \\
\hline Schefflera actinophylla & 329.08 \\
\hline Schefflera actinophylla & 236.85 \\
\hline Schefflera actinophylla & 149.89 \\
\hline Cordia sp. & $2,281.41$ \\
\hline Cordia sp. & $1,253.26$ \\
\hline Cordia sp. & $1,194.22$ \\
\hline Cordia sp. & $1,150.29$ \\
\hline Spathodea campanulata & $1,795.17$ \\
\hline Ficus benjamina & $4,330.00$ \\
\hline
\end{tabular}

(Continued) 
Table 2. Individual and sample total results valuation of the Itaim Paulista administrative district urban forest, Sao Paulo, Brazil (Continued).

\begin{tabular}{|c|c|}
\hline Scientific name & Monetary value (US\$) \\
\hline Ficus benjamina & $2,980.41$ \\
\hline Ficus benjamina & $2,767.45$ \\
\hline Ficus benjamina & $2,745.58$ \\
\hline Ficus benjamina & $2,182.41$ \\
\hline Ficus benjamina & $1,571.68$ \\
\hline Ficus guaranitica & $2,923.92$ \\
\hline Myrcia tomentosa & 712.68 \\
\hline Myrcia tomentosa & 503.47 \\
\hline Tabebuia sp. & $2,010.41$ \\
\hline Tabebuia pentaphylla & $1,375.92$ \\
\hline Myrciaria trunciflora & $1,989.78$ \\
\hline Artocarpus heterophyllus & $1,895.25$ \\
\hline Mangifera indica & 523.60 \\
\hline Mangifera indica & 376.08 \\
\hline Mangifera indica & 228.76 \\
\hline Licania tomentosa & $2,099.03$ \\
\hline Licania tomentosa & $1,550.92$ \\
\hline Licania tomentosa & $1,200.88$ \\
\hline Licania tomentosa & $1,197.66$ \\
\hline Licania tomentosa & $1,154.55$ \\
\hline Licania tomentosa & $1,153.19$ \\
\hline Licania tomentosa & $1,147.03$ \\
\hline Ceiba speciosa & $4,606.80$ \\
\hline Ceiba speciosa & $2,607.72$ \\
\hline Roystonea sp. & $1,519.40$ \\
\hline Bauhinia rufa & 862.32 \\
\hline Bauhinia rufa & 853.34 \\
\hline Bauhinia rufa & 688.99 \\
\hline Caesalpinia ferrea & 903.74 \\
\hline
\end{tabular}


Table 2. Individual and sample total results valuation of the Itaim Paulista administrative district urban forest, Sao Paulo, Brazil (Continued).

\begin{tabular}{lc}
\hline Scientific name & Monetary value (US\$) \\
\hline Caesalpinia ferrea & 738.00 \\
\hline Pinus sp. & 458.74 \\
\hline Eugenia uniflora & $1,382.36$ \\
\hline Lagerstroemia indica & 713.06 \\
\hline Caesalpinia pluviosa & $4,674.51$ \\
\hline Tipuana tipu & $2,203.75$ \\
\hline Tipuana tipu & 973.25 \\
\hline Aleurites fordii & $2,040.11$ \\
\hline & $\mathrm{US} \$ 84,765.24$ \\
\hline
\end{tabular}

Source: Original research data

\section{Nossa Senhora do Ó AD}

Within the selected sample area of 31,416 sq. meters, there are 46 individual trees with an estimated monetary value of US\$ 66,814.838, per $\mathrm{m}^{2}$ - value of US\$2.12.

For $\mathrm{Kr}$ calculation was considered the total planting costs of de US\$73.06 for Sao Paulo city (POTENZA, 2016) with the RII lowest value of 0.07 (Citrus limon), generating a final $\mathrm{Kr}=1,043.71$.

The generate indexes for valuation calculation and the monetary values for each arboreal individual, for Nossa Senhora do Ó AD, are listed in Table 3 and Table 4, respectively.

The evaluated trees with greater value were a Ligustrum lucidum (US\$ 5,297.91), and two Licania tomentosa (US\$ 3,885.46 e US\$3,645.07). Among these three trees are the highest $(20.61 \mathrm{~m})$, with higher DBH $(0.61 \mathrm{~m})$ and the highest value of first offshoot $(4.29 \mathrm{~m})$, respectively, being all very interesting characteristics for urban forest and are valued by the formula method. 
Table 3. Nossa Senhora do Ó Administration District indexes, being: condition value (CV), localization value (LV), biometric value (BV) specie value (SV), specie shrubs value (SSV), specie frequency $(\%)$, importance index (II) relative importance index (RII).

\begin{tabular}{|c|c|c|c|c|c|c|c|}
\hline Scientific name & $\mathbf{C V}$ & $\mathbf{L V}$ & BV & $\begin{array}{l}\text { SV } \\
\text { SSV }\end{array}$ & $\%$ & II & RII \\
\hline Ligustrum lucidum & 3 & 1 & 2.08 & 1.6 & 19.57 & 9.99 & 0.51 \\
\hline Ligustrum lucidum & 2 & 1 & 1.54 & 1.6 & 19.57 & 4.91 & 0.25 \\
\hline Ligustrum lucidum & 2 & 1 & 1.23 & 1.8 & 19.57 & 4.43 & 0.23 \\
\hline Ligustrum lucidum & 2 & 1 & 1.20 & 1.8 & 19.57 & 4.32 & 0.22 \\
\hline Ligustrum lucidum & 2 & 1 & 1.01 & 1.8 & 19.57 & 3.65 & 0.19 \\
\hline Ligustrum lucidum & 2 & 1 & 0.63 & 1.8 & 19.57 & 2.27 & 0.12 \\
\hline Ligustrum lucidum & 3 & 1 & 1.10 & 1.8 & 19.57 & 5.93 & 0.30 \\
\hline Ligustrum lucidum & 3 & 1 & 1.16 & 1.8 & 19.57 & 6.27 & 0.32 \\
\hline Ligustrum lucidum & 2 & 1 & 1.03 & 1.4 & 19.57 & 2.89 & 0.15 \\
\hline Eriobotrya japonica & 1 & 1 & 0.43 & 1.6 & 2.17 & 0.69 & 0.32 \\
\hline Cordia sp. & 2 & 1 & 0.41 & 2.2 & 10.87 & 1.80 & 0.17 \\
\hline Cordia sp. & 2 & 1 & 0.73 & 2.2 & 10.87 & 3.22 & 0.30 \\
\hline Cordia sp. & 2 & 1 & 0.26 & 2.2 & 10.87 & 1.15 & 0.11 \\
\hline Cordia sp. & 2 & 1 & 0.39 & 2.2 & 10.87 & 1.71 & 0.16 \\
\hline Cordia sp. & 2 & 1 & 0.30 & 2.2 & 10.87 & 1.33 & 0.12 \\
\hline Nerium oleander & 2 & 1 & 0.29 & 0.45 & 6.52 & 0.26 & 0.04 \\
\hline Nerium oleander & 2 & 1 & 0.38 & 0.45 & 6.52 & 0.34 & 0.05 \\
\hline Nerium oleander & 2 & 1 & 0.30 & 0.45 & 6.52 & 0.27 & 0.04 \\
\hline Myrcia tomentosa & 3 & 1 & 1.13 & 1.4 & 4.35 & 4.75 & 1.09 \\
\hline Myrcia tomentosa & 2 & 1 & 1.04 & 1.4 & 4.35 & 2.91 & 0.67 \\
\hline Grevillea robusta & 1 & 1 & 0.72 & 2.2 & 2.17 & 1.58 & 0.73 \\
\hline Jacaranda mimosifolia & 3 & 1 & 0.15 & 2.2 & 8.70 & 1.00 & 0.12 \\
\hline Jacaranda mimosifolia & 2 & 1 & 0.18 & 2.2 & 8.70 & 0.80 & 0.09 \\
\hline Jacaranda mimosifolia & 2 & 1 & 0.30 & 2.2 & 8.70 & 1.31 & 0.15 \\
\hline Jacaranda mimosifolia & 2 & 1 & 0.22 & 2.2 & 8.70 & 0.98 & 0.11 \\
\hline Plumeria rubra & 1 & 1 & 0.28 & 1.6 & 2.17 & 0.45 & 0.21 \\
\hline Citrus limon & 2 & 1 & 0.21 & 1.60 & 6.52 & 0.67 & 0.10 \\
\hline Citrus limon & 2 & 1 & 0.15 & 1.60 & 6.52 & 0.47 & 0.07 \\
\hline Citrus limon & 2 & 1 & 0.49 & 1.60 & 6.52 & 1.58 & 0.24 \\
\hline Mangifera indica & 3 & 1 & 0.30 & 1.6 & 6.52 & 1.44 & 0.22 \\
\hline
\end{tabular}


Table 3. Nossa Senhora do Ó Administration District indexes, being: condition value (CV), localization value (LV), biometric value (BV) specie value (SV), specie shrubs value (SSV), specie frequency $(\%)$, importance index (II) relative importance index (RII) (Continued).

\begin{tabular}{llllllll}
\hline Scientific name & CV & LV & BV & $\begin{array}{l}\text { SV } \\
\text { SSV }\end{array}$ & $\%$ & II & RII \\
\hline Mangifera indica & 2 & 1 & 0.24 & 1.6 & 6.52 & 0.78 & 0.12 \\
\hline Mangifera indica & 2 & 1 & 0.29 & 1.6 & 6.52 & 0.93 & 0.14 \\
\hline Licania tomentosa & 2 & 1 & 0.38 & 2.4 & 13.04 & 1.82 & 0.14 \\
\hline Licania tomentosa & 2 & 1 & 0.44 & 2.4 & 13.04 & 2.10 & 0.16 \\
\hline Licania tomentosa & 3 & 1 & 0.99 & 2.4 & 13.04 & 7.15 & 0.55 \\
\hline Licania tomentosa & 3 & 1 & 0.87 & 2.4 & 13.04 & 6.24 & 0.48 \\
\hline Licania tomentosa & 3 & 1 & 0.49 & 2.4 & 13.04 & 3.50 & 0.27 \\
\hline Licania tomentosa & 3 & 1 & 0.93 & 2.4 & 13.04 & 6.71 & 0.51 \\
\hline Roystonea sp. & 2 & 1 & 1.25 & 1.2 & 4.35 & 3.01 & 0.69 \\
\hline Roystonea sp. & 2 & 1 & 1.27 & 1.2 & 4.35 & 3.05 & 0.70 \\
\hline Eugenia uniflora & 1 & 1 & 0.75 & 3 & 2.17 & 2.25 & 1.03 \\
\hline Lagerstroemia indica & 1 & 1 & 0.80 & 3 & 2.17 & 2.41 & 1.11 \\
\hline Lagerstroemia speciosa & 1 & 1 & 0.65 & 3 & 2.17 & 1.95 & 0.90 \\
\hline Punica granatum & 3 & 1 & 0.78 & 0.55 & 6.52 & 1.28 & 0.20 \\
\hline Punica granatum & 2 & 1 & 0.70 & 0.55 & 6.52 & 0.77 & 0.12 \\
\hline Punica granatum & 2 & 1 & 0.46 & 0.55 & 6.52 & 0.50 & 0.08 \\
\hline Soure: Origin research & & & & & &
\end{tabular}

Source: Original research data

Table 4. Individual and sample total results valuation of the Nossa Senhora do Ó administrative district urban forest, Sao Paulo, Brazil.

\section{Scientific name}

Ligustrum lucidum

Ligustrum lucidum

Ligustrum lucidum

Ligustrum lucidum

Ligustrum lucidum

Ligustrum lucidum

Ligustrum lucidum

Ligustrum lucidum

Ligustrum lucidum
Monetary value (US\$)

$5,297.42$

$2,605.40$

$2,346.54$

$2,292.38$

$1,934.25$

$1,203.15$

$3,145.27$

3,326.99

$1,532.48$ 
Table 4. Individual and sample total results valuation of the Nossa Senhora do Ó administrative district urban forest, Sao Paulo, Brazil (Continued).

\begin{tabular}{ll}
\hline Scientific name & Monetary value (US\$) \\
\hline Eriobotrya japonica & 505.86 \\
\hline Cordia sp. & 989.81 \\
\hline Cordia sp. & $1,774.31$ \\
\hline Cordia sp. & 635.95 \\
\hline Cordia sp. & 939.50 \\
\hline Cordia sp. & 731.96 \\
\hline Nerium oleander & 152.70 \\
\hline Nerium oleander & 196.63 \\
\hline Nerium oleander & 154.96 \\
\hline Myrcia tomentosa & $2,950.13$ \\
\hline Myrcia tomentosa & $1,808.56$ \\
\hline Grevillea robusta & $1,166.44$ \\
\hline Jacaranda mimosifolia & 562.80 \\
\hline Jacaranda mimosifolia & 451.99 \\
\hline Jacaranda mimosifolia & 739.58 \\
\hline Jacaranda mimosifolia & 550.50 \\
\hline Plumeria rubra & 329.96 \\
\hline Citrus limon & 391.74 \\
\hline Citrus limon & 274.78 \\
\hline Citrus limon & 920.38 \\
\hline Mangifera indica & 451.03 \\
\hline Mangifera indica & 539.93 \\
\hline Licania tomentosa & 990.11 \\
\hline Licania tomentosa & $1,139.35$ \\
\hline Licania tomentosa & $3,885.10$ \\
\hline Licania tomentosa & $3,389.88$ \\
\hline Licania tomentosa & $1,900.43$ \\
\hline Licania tomentosa & $3,644.73$ \\
\hline Roystonea sp. & $1,865.90$ \\
\hline & \\
\hline
\end{tabular}


Table 4. Individual and sample total results valuation of the Nossa Senhora do Ó administrative district urban forest, Sao Paulo, Brazil (Continued).

\begin{tabular}{ll}
\hline Scientific name & Monetary value (US\$) \\
\hline Roystonea sp. & $1,894.75$ \\
\hline Eugenia uniflora & $1,654.86$ \\
\hline Lagerstroemia indica & $1,776.01$ \\
\hline Lagerstroemia speciosa & $1,436.78$ \\
\hline Punica granatum & 745.57 \\
\hline Punica granatum & 450.30 \\
\hline Punica granatum & 292.39 \\
\hline & $\mathrm{US} \$ 66,808.45$ \\
\hline
\end{tabular}

Source: Original research data

\section{Formulas comparison}

As proposed, shrubs species were identified in both inventories. The differences between formula results of Potenza (2016) (P) and the proposed in this research (A) can be seen in Table 5 for Itaim Paulista AD, and in Table 6 for Nossa Senhora do Ó AD.

The difference between the two formulas' monetary valuations and their SV, SSV and IR index values should be highlighted. This extreme difference is due to the (A) formula's discounting of all shrub species values relative to the $(\mathrm{P})$ formula. In monetary value alone, the $(\mathrm{A})$ formula discounted the species' total value by $75 \%$ from the $(\mathrm{P})$ formula value in the Itaim Paulista AD and by $86 \%$ in the Nossa Senhora do Ó AD.

Table 5. Detail comparison of monetary valuation of the Itaim Paulista Administrative District shrub species, with formula values by Potenza (P) and by Arantes et al. (2018) (A) .

\begin{tabular}{llllllllll}
\hline Species & VE (P) & VES (A) & $\begin{array}{l}\text { IR } \\
(\mathrm{P})\end{array}$ & IR (A) & IIR (P) & $\begin{array}{l}\text { IIR } \\
(\mathrm{A})\end{array}$ & $\begin{array}{l}\text { US\$ } \\
(\mathrm{P})\end{array}$ & $\begin{array}{l}\text { US\$ } \\
(\mathrm{A})\end{array}$ & $\begin{array}{l}\text { Difference } \\
(\mathrm{US} \$)\end{array}$ \\
\hline $\begin{array}{l}\text { Schefflera } \\
\text { actinophylla }\end{array}$ & 1.8 & 0.45 & 10.97 & 2.74 & 1.56 & 0.39 & $1,330.55$ & 332,64 & 997,92 \\
\hline $\begin{array}{l}\text { Schefflera } \\
\text { actinophylla }\end{array}$ & 1.8 & 0.45 & 10.85 & 2.71 & 1.55 & 0.39 & $1,316.30$ & 329,08 & 987,23 \\
\hline $\begin{array}{l}\text { Schefflera } \\
\text { actinophylla }\end{array}$ & 1.8 & 0.45 & 7.81 & 1.95 & 1.11 & 0.28 & 947.38 & 236,85 & 710,54 \\
\hline $\begin{array}{l}\text { Schefflera } \\
\text { actinophylla }\end{array}$ & 1.8 & 0.45 & 4.94 & 1.24 & 0.7 & 0.18 & 599.54 & 149,89 & 449,66 \\
\hline \begin{tabular}{l} 
Total \\
\hline
\end{tabular} & & & & & & & $4,193.79$ & $1,048.47$ & $3,145.34$ \\
\hline
\end{tabular}

Source: Original research data 
Table 6. Detail comparison of monetary valuation of Nossa Senhora do Ó Administrative District shrub species, with formula values by Potenza (P) and by Arantes et al. (2018) (A).

\begin{tabular}{llllllll}
\hline Species & SSV (P) & SSV (A) & RII (P) & $\begin{array}{l}\text { RII } \\
(\mathbf{A})\end{array}$ & US\$ (P) & US\$ (A) & Difference (US\$) \\
\hline Nerium oleander & 1.8 & 0.45 & 0.16 & 0.04 & $1,099.12$ & 152.84 & 946,28 \\
\hline Nerium oleander & 1.8 & 0.45 & 0.21 & 0.05 & $1,413.99$ & 196.62 & $1,217.36$ \\
\hline Nerium oleander & 1.8 & 0.45 & 0.16 & 0.04 & $1,114.32$ & 154.95 & 959.36 \\
\hline Punica granatum & 2.2 & 0.55 & 0.79 & 0.20 & $5,361,61$ & 745.571 & $4,616.03$ \\
\hline Punica granatum & 2.2 & 0.55 & 0.47 & 0.12 & $3,238.21$ & 450.29 & $2,787.91$ \\
\hline Punica granatum & 2.2 & 0.55 & 0.31 & 0.08 & $2,102.65$ & 292.39 & $1,810.26$ \\
\hline Total & & & & & & & \\
\hline
\end{tabular}

Source: Original research data

The kr constant for Nossa Senhora do Ó AD, in this paper, was estimated in 0.07 (Citrus limon), what by the Potenza (2016) formula would be 0.04 (Nerium oleander) but following the proposed adjustment the shrubs species should not be considered. This new interpretation of valuation formula changes all species values, not just shrubs, and the differences in total values of both the (A) formula and the $(\mathrm{P})$ formula are in Table 7.

Table 7. Comparation between total monetary valuation and $\mathrm{Kr}$ constant, by Potenza (2016) and Arantes et al. (2018) (A), for Nossa Senhora do Ó AD and Itaim Paulista AD, in Sao Paulo/Brazil.

\begin{tabular}{lllll}
\hline Nossa Senhora do Ó & \multicolumn{3}{c}{ Itaim Paulista } \\
\hline Formula & Kr & Total & Kr & Total \\
\hline Potenza (2016) & $5,861.50$ & US\$ 130,857.05 & 681,56 & US\$ 87,910.57 \\
\hline A & $3,237.79$ & US\$ 66,808.59 & 681,56 & US\$ 84,765.23 \\
\hline Difference & & US\$ 64,048.46 & & US\$ 3,145,34 \\
\hline
\end{tabular}

Source: Original research data 
For Itaim Paulista $\mathrm{AD}$ there was no difference between $\mathrm{Kr}$ constant, being the smallest RII by both formulas a tree species. So, it is possible to state that when the $\mathrm{Kr}$ constant is changed, these differences are accentuated, modifying all the valuation, both for tree and shrub, which it's possible to see in Nossa Senhora do Ó AD, where the total difference is $51 \%$ among the total values.

It is very important that data such as these be generated for the cities and applied to their management, which is not often due to the lack of knowledge of forest valuation by urban managers.

An example of the proposed use of hedonic awareness to adjust property values is found in a study of Castellón, Spain, by Morancho (2003). The proposal worked from the premise that similar residential properties (number of bedrooms, bathrooms, etc.) located an equal distance from downtown should have their prices differentiated using the normal differentiating characteristics with the addition of a factor that accounts for the amount of available green area near the property, hypothesizing that property values should be affected by the aesthetics and well-being that green areas offer (MORANCHO, 2003).

\section{CONCLUSIONS}

The two São Paulo administrative districts studied contain monetarily valuable urban forest. Both administrative districts contained mature tall trees from diverse species.

The formula method enhancements were very positive and should be considered a new valuation model for future research, for futures studies, an interesting propose would be add hedonic considerations to formula method.

\section{REFERENCES}

ATLAS BRASIL. 2016 Ranking São Paulo 2010. Available in: <http://atlasbrasil.org.br/2013/pt/ranking>. Accessed on Sept. 2016.

ARANTES, B.L. 2017. Arborização urbana e qualidade do ar na cidade de São Paulo. 87p. Thesis presented to obtain a master's degree in Forest Resources, in University of São Paulo, Piracicaba.

AYUGA-TÉLlEZ, E.; CONTATO-CAROL, M. L.; GONZÁLEZ, C.; GRANDE-ORTIZ, M. A.; VELÁZQUEZ, J. 2011. Applying multivariate data analysis as objective method for calculating the location index for use in urban tree appraisal. Journal of Urban Planning and Development, New York, v. 137, n. 3, p. 230-237.

BLUM, C. T.; BORGO, M.; SAMPAIO, A. C. F. 2008. Espécies exóticas invasoras na arborização de vias públicas de Maringá-PR. Revista da Sociedade Brasileira de Arborização Urbana, Piracicaba, v. 3, n. 2, p. 78-97.

CENTER FOR URBAN FOREST RESEARCH. 2006. The Large Tree Argument: The Case for Large Trees vs. Small Trees. USDA Forest Service, Davis, CA, p. 1-8. 
EDWARDS, R. 1992. Tree evaluation schemes - making the right choice? Horticulture in New Zealand, Wellington, v.3, n.1, p. 21-29.

FALCO, G. P. 2010. Porque quantificar o meio ambiente? Revista Vianna Sapiens, Juiz de Fora, v.1, n.2, p.1-28.

FAUSET, S.; JOHNSON, M. O.; GLOOR, M.; BAKER, T. R.; MONTEAGUDO, A.; BRIENEN, R. J.; PITMAN, N. C. 2015. Hyper dominance in Amazonian forest carbon cycling. Nature communications, London, v. 6, p. 6857.

GREY, G. W.; DENEKE, F. J. 1986. Urban forestry. 2nd ed. New York: John Wiley, 299 p.

IBAMA. Portaria n. 37-N, 3 abr. 1992. Available in: <http://www.mma.gov.br/estruturas/179/_arquivos/179_05122008033627.pdf.>. Accessed on 1 June 2017.

ITO, K.; WEINBERGER, K. R.; ROBINSON, G. S.; SHEFFIELD, P. E.; LALL, R.; MATHES, R.; ROSS, Z; KINNEY, P L; MATTE, T. D. 2015. The associations between daily spring pollen counts, over-the-counter allergy medication sales, and asthma syndrome emergency department visits in New York City, 2002-2012. Environmental Health, v.14, n.1, p.71-80.

LO, A. Y.; JIM, C. Y. 2010. Willingness of residents to pay and motives for conservation of urban green spaces in the compact city of Hong Kong. Urban Forestry \& Urban Greening, Jena, v.9, n.2, p. 113-120.

LOVASI, G. S.; O’NEIL-DUNNE, J. P.; LU, J. W.; SHEEHAN, D.; PERZANOWSKI, M. S.; MACFADEN, S. W.; KING, K. L.; MATTE, T.; MILLER, R. L.; HOEPNER, L. A.; PERERA, F. P.; RUNDLE A. 2013. Urban tree canopy and asthma, wheeze, rhinitis, and allergic sensitization to tree pollen in a New York city birth cohort. Environmental Health Perspectives, v.121, n.4, p.494500.

MASCARÓ L.; MASCARÓ, J. L. 2010. Vegetação Urbana. Porto Alegre, $3^{a}$ edição, 212 p.

MORANCHO, A. B. 2003. A hedonic valuation of urban green areas. Landscape and urban planning, v. 66 , n. 1 , p. $35-41$.

MOTA, J. A. 2001. O valor da natureza: economia e política dos recursos ambientais. $2^{\mathrm{a}}$ ed. Rio de Janeiro: Garamond, 198p.

PRIMACK, R. B.; RODRIGUES, E. 2006. Biologia da conservação. Editora Efraim Rodrigues, p. 1327.

POTENZA, R. F. 2016. Métodos de fórmula para valoração econômica de árvores nas cidades. Thesis presented to obtain a master's degree in Forest Resources. University of São Paulo.

RHODES, J. R.; NG, C. F.; DE VILLIERS, D. L.; PREECE, H. J.; MCALPINE, C. A.; POSSINGHAM, H. P. 2011. Using integrated population modelling to quantify the implications of multiple threatening processes for a rapidly declining population. Biological Conservation, Essex, v. 144, n. 3, p. 1081-1088.

ROCHA, Y. T.; BARBEDO, A. S. C. 2008. Pau-brasil (Caesalpinia echinata L.., Leguminosae) na arborização urbana de São Paulo (SP), Rio de Janeiro (RJ) e Recife (PE). Revista SBAU, n. 3, p. 58-77.

ROCHA, R. T. D.; LELES, P. S. D. S.; OLIVEIRA NETO, S. N. D. 2004. Arborização de vias públicas em Nova Iguaçu, RJ: o caso dos bairros Rancho Novo e Centro. Revista Árvore, Viçosa, MG, $\mathrm{n}$. 28, v. 4, p. 599-607.

SANDER, H.; POLASKY, S.; HAIGHT, R. G. 2010. The value of urban tree cover: a hedonic property price model in Ramsey and Dakota Counties, Minnesota, USA. Ecological Economics, Amsterdam, v. 69, n. 8 , p. $1646-1656$. 
SEAMANS, G. S. 2013. Main streaming the environmental benefits of street trees. Urban Forestry \& Urban Greening, Washington, v.12, n.1, p. 2-11.

SILVA FILHO, D. F.; PIZETTA, P. U. C.; DE ALMEIDA, J. B. S. A.; PIVETTA, K. F. L.; FERRAUD, S. 2002. Banco de dados relacional para cadastro, avaliação e manejo da arborização em vias públicas. Revista Árvore, Viçosa, v. 26, n. 5, p. 629-642.

SILVA FILHO, D. F.; TOSETTI, L. L. 2010. Valoração das árvores no Parque Ibirapuera - SP: importância da infraestrutura verde urbana. Revista LabVerde, São Paulo, n. 1 p. 11-25.

SMITH, V. K.; HUANG, J. 1995. Can markets value air quality? A meta-analysis of hedonic property value models. Journal of Political Economy, Chicago, v. 103, n. 1, p. 209-227.

VIANA, S. M.; TOSETTI, L. L.; ROLLO, L. C. P.; SILVA FILHO, D. F. 2012. Valoração monetária: pesquisas em floresta urbana. Revista SBAU, Piracicaba, v. 7, n. 1, p. 76-88.

WATSON, G. 2002. Comparing formula methods of tree appraisal. Journal of Arboriculture, Champaign, v. 28, n. 1, p. 11-18.

WOLF, K. L. 2004. O valor econômico e social das florestas urbanas. Revista de Agricultura Urbana, Leusden, v. 1, n. 13, p. 32-35. 